\title{
Leuconostoc gelidum sp. nov. and Leuconostoc carnosum sp. nov. from Chill-Stored Meats
}

\author{
B. G. SHAW* AND C. D. HARDING \\ Department of Microbiology, Agricultural and Food Research Council, Institute of Food Research, Bristol Laboratory, \\ Langford, Bristol BS18 7DY, United Kingdom
}

\begin{abstract}
A numerical taxonomic study was performed on 52 Leuconostoc spp. strains isolated from chill-stored meats. Three clusters were observed; representative strains from these clusters, together with the type strains of previously described species, were examined by performing a cellular fatty acid analysis and deoxyribonucleic acid (DNA)-DNA hybridization. Cluster II contained seven strains, which were assigned to Leuconostoc mesenteroides subsp. mesenteroides on the basis of DNA relatedness and biochemical properties. Clusters I ( 30 strains) and III (15 strains) were shown to represent two new species, for which thc names Leuconostoc gelidum and Leuconostoc carnosum, respectively, are proposed. The type strains of $L$. gelidum and $L$. carnosum are strains NCFB 2775 and NCFB 2776, respectively.
\end{abstract}

The genus Leuconostoc is presently composed of four species, viz., Leuconostoc mesenteroides (containing three subspecies, Leuconostoc mesenteroides subsp. mesenteroides, Leuconostoc mesenteroides subsp. dextranicum, and Leuconostoc mesenteroides subsp. cremoris), Leuconostoc paramesenteroides, Leuconostoc lactis, and Leuconostoc oenos (8). This classification is based on phenotypic characteristics, including nutritional requirements $(3,5)$, immunological relationships of dehydrogenases $(10,13)$, and deoxyribonucleic acid (DNA) homologies $(6,14)$.

The habitats of all of these species except Leuconostoc oenos are reported to be milk and dairy products and plant material; Leuconostoc oenos is isolated only from wine and related habitats $(8,21)$. However, there have been several reports of leuconostocs occurring among the dominant microbial population on meats stored in vacuum packs or under modified gas atmospheres containing carbon dioxide $(1,11$, 20,22 ), where they may contribute to spoilage. Some isolates from meat have been identified by using an early classification scheme (3) as belonging to groups equivalent to Leuconostoc mesenteroides subsp. mesenteroides or Leuconostoc paramesenteroides $(1,20)$. However, in our experience many isolates are not identifiable as any of the previously described species.

In this study we used numerical taxonomic techniques to group leuconostocs from stored packaged meats and determined the relationships of the groups to the previously described species. Groups were also studied by performing a cellular fatty acid analysis and DNA homology experiments, which revealed two new species, for which the names Leuconostoc gelidum and Leuconostoc carnosum are proposed.

\section{MATERIALS AND METHODS}

Strains studied. A total of 52 Leuconostoc spp. strains from eight samples of raw and cooked vacuum-packed meats were examined (Table 1). The isolates deemed to be leuconostocs were gram-positive, catalase-negative cocci or coccobacilli that produced gas from glucose and formed more than $95 \%$ of their lactate as the $\mathrm{D}-(-)$ isomer. The type strains of five of the six Leuconostoc species and subspecies described in Bergey's Manual of Systematic Bacteriology,

\footnotetext{
* Corresponding author.
}

vol. 2 (8), were included for reference purposes. The type strain of Leuconostoc oenos was not included, as this species was known to differ from the meat strains in its requirement for special media with a $\mathrm{pH}$ of 4.8 or less (5).

Cultures were maintained at 0 to $1^{\circ} \mathrm{C}$ in cooked meat medium and were subcultured every 3 months. Except where otherwise stated, inocula for tests were grown in $\mathrm{BM}$ broth (28) incubated at $20^{\circ} \mathrm{C}$.

Morphological, physiological, and biochemical tests. Gram reaction and morphology were determined after $24 \mathrm{~h}$ of incubation of TSY agar (12). Gas production from glucose, ammonia production from arginine, reduction of $0.01 \%$ 2,3,5-triphenyltetrazolium chloride, and sugar fermentation were determined as described by Shaw and Harding (23), and acetoin production and hydrolysis of esculin were determined as described by Wilkinson and Jones (28). The isomer of lactate formed from glucose was determined by using the procedure of Shaw and Harding (22), except that D-lactate and L-lactate were determined enzymatically by using reagents obtained from Boehringer $\mathrm{GmbH}$, Mannheim, Federal Republic of Germany. The $o$-nitrophenyl- $\beta$-D-galactopyranoside test was performed by using the method of Lowe (18). All other tests were performed as described by Shaw and Harding (22).

Computer analysis of phenetic data. A total of 23 characters were identical for all strains and were omitted from the calculation of similarities among strains. The remaining 23 characters were coded in the following states: 1 (positive) and 2 (negative). The level of similarity among strains was estimated by using the simple matching coefficient of Sokal and Michener (25) and clustering by unweighted pair-group average linkage analysis (25).

The 23 tests giving varied results for different strains were repeated with $10 \%$ of the strains to determine test reproducibility.

Cellular fatty acids. Cultures were grown in Trypticase soy broth (BBL Microbiology Systems, Cockeysville, Md.) supplemented with $3 \mathrm{~g}$ of Lab Lemco (Oxoid Ltd., Basingstoke, United Kingdom) per liter. Cells were harvested by centrifugation $(10,000 \times g, 10 \mathrm{~min})$ following static incubation of $200 \mathrm{ml}$ of medium in $250-\mathrm{ml}$ Duran bottles for $72 \mathrm{~h}$ at $20^{\circ} \mathrm{C}$. Then 40 to $60 \mathrm{mg}$ (wet weight) of cells was transferred to a screw-cap tube and saponified with $1 \mathrm{ml}$ of $15 \%(\mathrm{wt} / \mathrm{vol})$ $\mathrm{NaOH}$ in $50 \%$ aqueous methanol for $30 \mathrm{~min}$ at $100^{\circ} \mathrm{C}$ with Vortex mixing initially and after $25 \mathrm{~min}$. After cooling, the 
TABLE 1. Strains studied

\begin{tabular}{|c|c|c|c|c|c|}
\hline Cluster & Name as received & $\begin{array}{l}\text { No. of } \\
\text { strains }\end{array}$ & $\begin{array}{c}\text { Strain } \\
\text { designation(s) }\end{array}$ & Source & Isolated from: \\
\hline I (Leuconostoc gelidum) & Leuconostoc spp. & 30 & $\begin{array}{l}\text { SML1 to SML3, } \\
\text { SML5 to SML30, } \\
\text { SML52 }\end{array}$ & Our isolates & Vacuum-packaged beef \\
\hline \multirow[t]{2}{*}{$\begin{array}{l}\text { II (Leuconostoc mesenteroides } \\
\text { subsp. mesenteroides) }\end{array}$} & Leuconostoc spp. & 7 & $\begin{array}{l}\text { SML41 to SML45, } \\
\text { SML45, SML50 }\end{array}$ & Our isolates & $\begin{array}{l}\text { Vacuum-packaged } \\
\text { cooked ham }\end{array}$ \\
\hline & $\begin{array}{l}\text { Leuconostoc mesenteroides } \\
\text { subsp. mesenteroides }\end{array}$ & 1 & $\begin{array}{l}\text { NCFB } 523^{\mathrm{T}} \\
\left(=\text { ATCC } 8293^{\mathrm{T}}\right)\end{array}$ & $\mathrm{NCFB}^{a}$ & Fermenting olives \\
\hline III (Leuconostoc carnosum) & Leuconostoc spp. & 15 & $\begin{array}{l}\text { SML31 to SML40 } \\
\text { SML46, SML48, } \\
\text { SML49, SML51, } \\
\text { SML53 }\end{array}$ & Our isolates & $\begin{array}{l}\text { Vacuum-packaged beef, } \\
\text { pork, bacon, cooked } \\
\text { ham, and luncheon } \\
\text { meat }\end{array}$ \\
\hline \multirow[t]{4}{*}{ Unclustered } & $\begin{array}{l}\text { Leuconostoc mesenteroides } \\
\text { subsp. dextranicum }\end{array}$ & 1 & NCFB $529^{\mathrm{T}}$ & $\mathrm{NCFB}$ & Unknown \\
\hline & $\begin{array}{l}\text { Leuconostoc mesenteroides } \\
\text { subsp. cremoris }\end{array}$ & 1 & $\mathrm{NCFB} 543^{\mathrm{T}}$ & NCFB & Dried starter powder \\
\hline & Leuconostoc paramesenteroides & 1 & NCFB $803^{\mathrm{T}}$ & NCFB & Unknown \\
\hline & Leuconostoc lactis & 1 & NCFB $533^{\mathrm{T}}$ & NCFB & Milk \\
\hline
\end{tabular}

${ }^{a}$ NCFB, National Collection of Food Bacteria, Agricultural and Food Research Council, Institute of Food Research, Reading Laboratory, Shinfield, Reading, United Kingdom.

released fatty acids were converted to methyl esters by adding $2 \mathrm{ml}$ of $54 \%$ ( $\mathrm{vol} / \mathrm{vol}) 6 \mathrm{~N} \mathrm{HCl}$ in methanol, followed by heating at $80^{\circ} \mathrm{C}$ for $10 \mathrm{~min}$ and then rapid cooling in cold running water. The methyl esters were extracted into $1.25 \mathrm{ml}$ of hexane-ether $(1: 1)$ by gentle mixing on a specimen tum- bler for $10 \mathrm{~min}$. The phases were allowed to separate, and the lower (aqueous) phase was discarded. The sample was then washed with $3 \mathrm{ml}$ of $1.2 \%$ (wt/vol) $\mathrm{NaOH}$ by mixing on a specimen tumbler for $5 \mathrm{~min}$. Then 2 drops of a saturated $\mathrm{NaCl}$ solution was added to assist separation of the phases.

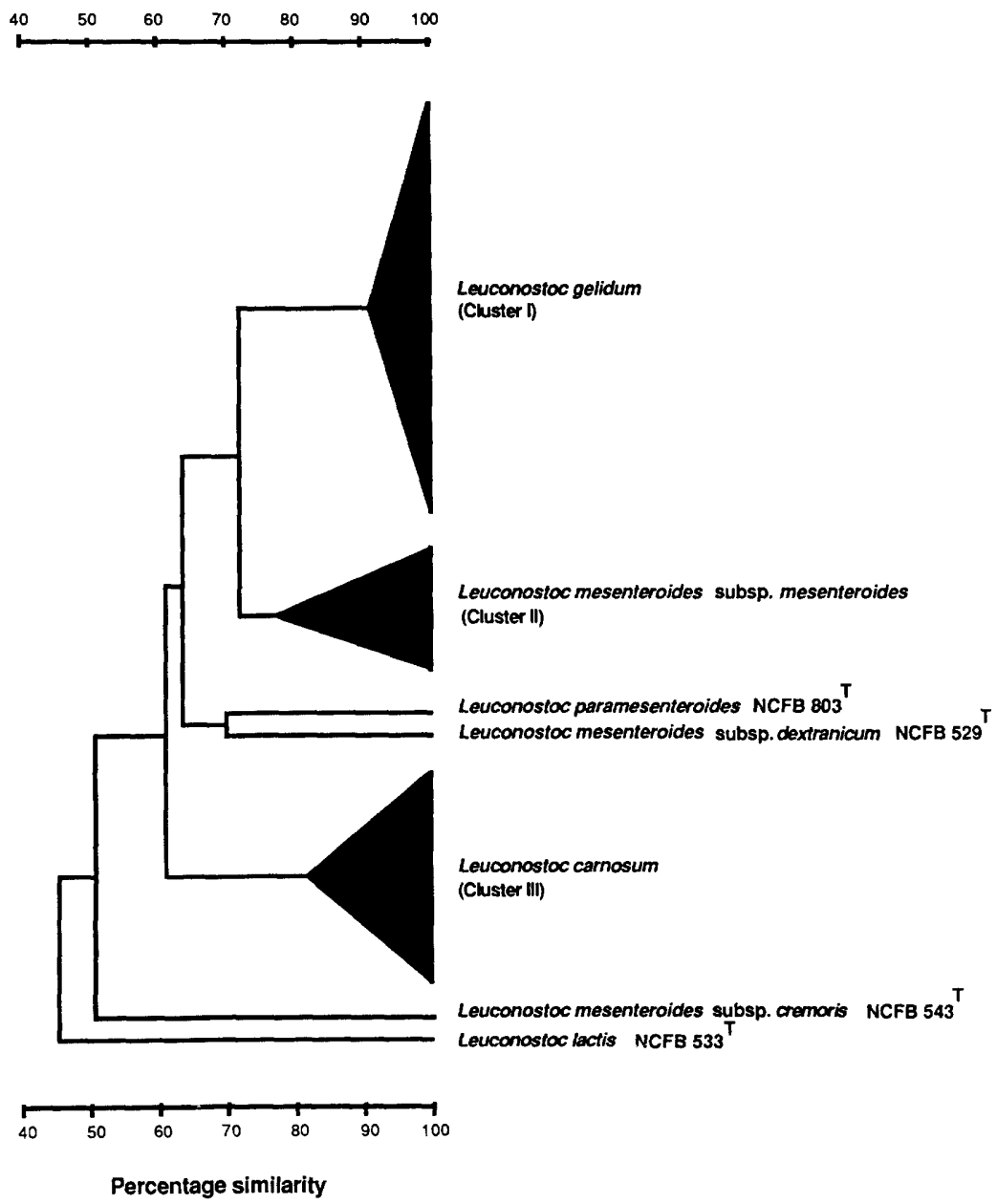

FIG. 1. Simplified dendrogram showing the phenotypic relationships of Leuconostoc species as determined by a numerical analysis. 
TABLE 2. Properties of the three clusters of leuconostocs detected at a similarity level of $78 \%$

\begin{tabular}{|c|c|c|c|}
\hline \multirow[b]{2}{*}{ Characteristic } & \multicolumn{3}{|c|}{$\%$ of strains positive } \\
\hline & $\begin{array}{c}\text { Cluster I } \\
\text { (Leuconostoc } \\
\text { gelidum; } \\
n=30)^{b}\end{array}$ & $\begin{array}{c}\text { Cluster II } \\
\text { (Leuconostoc } \\
\text { mesenteroides } \\
\text { subsp. mesen- } \\
\text { teroides; } n=8 \text { ) }\end{array}$ & $\begin{array}{c}\text { Cluster III } \\
\text { (Leuconostoc } \\
\text { carnosum; } \\
n=15)\end{array}$ \\
\hline Growth at $37^{\circ} \mathrm{C}$ & 3 & 100 & 7 \\
\hline Dextran formation & 80 & 100 & 93 \\
\hline $\mathrm{ONPG}^{c}$ & 100 & 100 & 0 \\
\hline Esculin hydrolysis & 100 & 100 & 66 \\
\hline \multicolumn{4}{|l|}{ Hydrolysis of: } \\
\hline Tween 40 & 0 & 0 & 27 \\
\hline Tween 60 & 0 & 88 & 13 \\
\hline \multicolumn{4}{|l|}{ Acid production from: } \\
\hline Amygdalin & 100 & 13 & 0 \\
\hline L-Arabinose & 100 & 100 & 0 \\
\hline Arbutin & 100 & 0 & 0 \\
\hline Cellobiose & 100 & 13 & 6 \\
\hline Galactose & 0 & 100 & 0 \\
\hline Lactose & 0 & 13 & 0 \\
\hline Maltose & 47 & 100 & 7 \\
\hline D-Mannose & 100 & 100 & 80 \\
\hline Melibiose & 100 & 100 & 13 \\
\hline$\alpha$-Methyl-D-glucoside & 100 & 25 & 100 \\
\hline Raffinose & 100 & 88 & 0 \\
\hline Ribose & 63 & 0 & 27 \\
\hline Salicin & 100 & 13 & 7 \\
\hline D-Xylose & 100 & 88 & 0 \\
\hline
\end{tabular}

${ }^{a}$ All strains produced gas from glucose, produced $>95 \%$ of their lactate as the $\mathrm{D}-(-)$ isomer, grew on acetate agar, grew at $4^{\circ} \mathrm{C}$, produced deoxyribonuclease, and produced acid from D-fructose, D-glucose, sucrose, and trehalose. All strains were negative for arginine dihydrolase, acetoin production, reduction of $0.01 \%$ tetrazolium, and hydrolysis of Tween 20 and Tween 80 , and none produced acid from D-arabinose, dulcitol, erythritol, gluconate, glycerol, inositol, mannitol, D-melezitose, rhamnose, sorbitol, or L-sorbose.

${ }^{b} n$ is the number of strains tested.

c $o$-Nitrophenyl- $\beta$-D-galactopyranoside.

The upper phase was transferred to a gas chromatography autosampler vial and sealed with a crimp cap.

The fatty acid methyl esters were analyzed by using a model 5890 flame ionization gas chromatograph (HewlettPackard Co., Avondale, Pa.) equipped with a fused silica capillary column $(25 \mathrm{~m}$ by $0.2 \mathrm{~mm})$ coated with a $0.33-\mu \mathrm{m}$ film of cross-linked 5\% phenyl methyl silicone (part numbers 19091B-102; Hewlett-Packard) at a column temperature programmed from 170 to $310^{\circ} \mathrm{C}$ at $5^{\circ} \mathrm{C} / \mathrm{min}$. Data were recorded with a model 3392A electronic integrator (Hewlett-Packard), and fatty acid methyl esters were identified by computer (series 300; Hewlett-Packard) comparison of retention times with retention times of authentic standards (part number 19298-60500 Rev. B; Hewlett-Packard).

DNA base composition and DNA-DNA hybridization. To prepare DNA, cells harvested from BM broth incubated for $18 \mathrm{~h}$ at $25^{\circ} \mathrm{C}$ were lysed overnight at $37^{\circ} \mathrm{C}$ with lysozyme and proteinase $\mathrm{K}$ (self digested) in 3\% 4-aminosalicylate, as described by Garvie (6). DNA was extracted and purified by the procedure of Owen and Pitcher (19). DNA base composition was estimated by the thermal denaturation method, as described by Garvie (7). DNA to be used in hybridization tests was labeled by nick translation with [methyl${ }^{3} \mathrm{H}$ ]thymidine triphosphate (kit N5500; Amersham International plc, Amersham, Buckinghamshire, England). DNA homology values were determined by using the $S 1$ nuclease procedure (2) as described by Owen and Pitcher (19). Hy- bridizations were performed for $18 \mathrm{~h}$ under optimum conditions $\left(25^{\circ} \mathrm{C}\right.$ below the thermal denaturation temperature).

\section{RESULTS}

Clustering of strains based on phenetic data. The relationships of strains revealed by the numerical analysis are shown in the simplified dendrogram in Fig. 1. The average probability of error, which was calculated from the repeated test results by using the formula of Sneath and Johnson (24), was $0.6 \%$, which would not produce a serious distortion of taxonomic structure. The cophenetic correlation value was 0.94 , showing that the dendrogram gives a good depiction of the relationships among strains.

Of the 57 strains examined, 53 were contained in three clusters (clusters I, II, and III) at a similarity level of $78 \%$. These clusters contained all 52 strains isolated from meat. Strain NCFB $523^{\mathrm{T}}$ ( $\mathrm{T}=$ type strain) (Leuconostoc mesenteroides subsp. mesenteroides) was present in cluster II, but the other four reference strains, strains NCFB $529^{\mathrm{T}}$ ( Leuconostoc mesenteroides subsp. dextranicum), NCFB $543^{\mathrm{T}}$ (Leuconostoc mesenteroides subsp. cremoris), NCFB $803^{\mathrm{T}}$ (Leuconostoc paramesenteroides), and NCFB 533 ${ }^{\mathrm{T}}$ (Leuconostoc lactis), were distinct from clusters I, II, and III.

Physiological and biochemical properties of the clusters. As is typical of leuconostocs, no strain hydrolyzed arginine and all of the strains produced $>95 \%$ of their lactate as the D- $(-)$ isomer (Table 2). Dextran formation was common in all three clusters. All cluster II strains grew at $37^{\circ} \mathrm{C}$, whereas clusters I and III contained high percentages of strains that were incapable of growth at this temperature. Otherwise, differences in the properties of the clusters occurred mainly in the fermentation tests, in which cluster III strains were relatively inactive.

Cellular fatty acid composition. All of the strains had cellular fatty acid profiles consisting of straight-chain saturated, monounsaturated, and cyclopropane ring acids (Table $3)$. The following fatty acids were detected in all strains: tetradecanoic $\left(\mathrm{C}_{14: 0}\right)$, cis-9,10-hexadecenoic $\left(\mathrm{C}_{16: 1} \Delta 9\right)$, hexadecanoic $\left(\mathrm{C}_{16: 0}\right)$, cis-11,12-octadecenoic $\left(\mathrm{C}_{18: 1} \Delta 11\right)$, and cis-11,12-methyleneoctadecanoic $\left(\mathrm{C}_{\text {cyclo-19 }} \Delta 11\right)$ acids. Despite this qualitative similarity, two different fatty acid profiles were discerned among the three clusters of strains isolated from meat. Cluster I strains and 4 of the 10 cluster III strains had lower cis-11,12-octadecenoic acid contents (7 to $17.5 \%$ ) and higher cis-11,12-methyleneoctadecanoic acid contents ( 21 to $29 \%$ ) than the cluster II strains and the other cluster III strains, which had cis-11,12-octadecenoic acid contents of 21 to $29 \%$ and cis-11,12-methyleneoctadecanoic acid contents of 4.5 to $9 \%$. The former group also contained 1.5 to $5.5 \%$ of methylenehexadecanoic acid, which was not detected in the other fatty acid profile group.

The type strains of the three subspecies of Leuconostoc mesenteroides (strains NCFB $523^{\mathrm{T}}$, NCFB $529^{\mathrm{T}}$, and NCFB $543^{\mathrm{T}}$ ) all had fatty acid profiles similar to those of the cluster II strains. The fatty acid profile of Leuconostoc paramesenteroides NCFB $803^{\mathrm{T}}$ was notable for a relatively low cis9,10-hexadecenoic acid content (4\%) and a high cis-11,12octadecenoic acid content (46.5\%). Leuconostoc lactis NCFB $533^{\mathrm{T}}$ contained a small amount of octadecanoic acid; this acid was not detected in any other strain.

DNA base composition and DNA-DNA hybridization. Strains in cluster I were 81 to $114 \%$ homologous with their reference strain (strain SML9T) and exhibited low levels of DNA base sequence relatedness to reference strains from the other clusters and type strains of previously described 
TABLE 3. Cellular fatty acid compositions

\begin{tabular}{|c|c|c|c|c|c|c|c|c|}
\hline \multirow{2}{*}{ Strain } & \multicolumn{8}{|c|}{ Fatty acid composition $(\%)^{a}$} \\
\hline & $\mathrm{C}_{14: 0}$ & $C_{16: 1} \Delta 9$ & $\mathrm{C}_{16: 1}$ trans -9 & $C_{16: 0}$ & $\mathrm{C}_{\text {cyclo-17 }}$ & $C_{18: 1} \Delta 11$ & $\mathrm{C}_{18: 0}$ & $\mathrm{C}_{\text {cyclo-19 } 19 \Delta 11}$ \\
\hline \multicolumn{9}{|l|}{ Leuconostoc gelidum (cluster I) } \\
\hline SML1 & 11.0 & 20.5 & & 33.5 & 2.0 & 7.5 & & 24.5 \\
\hline SML7 & 9.5 & 19.0 & & 32.5 & 2.0 & 7.0 & & 29.0 \\
\hline SML9 ${ }^{\mathrm{T}}$ & 9.5 & 19.0 & & 31.5 & 2.5 & 7.0 & & 29.5 \\
\hline SML10 & 9.5 & 19.5 & & 30.5 & 1.5 & 10.5 & & 28.5 \\
\hline SML28 & 10.5 & 19.0 & & 31.5 & 1.5 & 7.5 & & 28.5 \\
\hline \multicolumn{9}{|l|}{$\begin{array}{l}\text { Leuconostoc mesenteroides subsp. mesenteroides } \\
\text { (cluster II) }\end{array}$} \\
\hline NCFB $523^{\mathrm{T}}$ & 8.5 & 29.0 & & 34.5 & & 18.5 & & 9.0 \\
\hline SML42 & 7.5 & 27.5 & & 31.5 & & 28.0 & & 4.5 \\
\hline SML43 & 6.0 & 25.0 & & 33.0 & & 30.0 & & 5.5 \\
\hline SML44 & 7.5 & 27.5 & & 32.5 & & 27.5 & & 5.5 \\
\hline SML45 & 7.0 & 27.0 & & 31.5 & & 29.5 & & 4.5 \\
\hline SML50 & 7.0 & 25.5 & & 31.0 & & 29.5 & & 5.5 \\
\hline \multicolumn{9}{|l|}{ Leuconostoc carnosum (cluster III) } \\
\hline SML31 & 5.5 & 15.0 & $\mathrm{~V}$ & 34.0 & & 37.5 & & 6.5 \\
\hline SML33 & 5.5 & 15.0 & & 35.5 & & 37.5 & & 4.5 \\
\hline SML34 & 5.5 & 15.5 & & 34.0 & & 37.0 & & 6.0 \\
\hline SML35 & 5.5 & 18.0 & & 35.5 & & 35.0 & & 5.0 \\
\hline SML38 & 6.0 & 17.5 & & 35.0 & & 34.5 & & 5.5 \\
\hline $\mathrm{SML} 40^{\mathrm{T}}$ & 5.5 & 18.5 & & 34.5 & & 35.5 & & 4.5 \\
\hline SML48 & 7.5 & 16.5 & & 33.5 & 3.5 & 17.5 & & 21.0 \\
\hline SML49 & 7.0 & 12.0 & & 35.5 & 4.0 & 11.0 & & 28.5 \\
\hline SML51 & 5.5 & 10.5 & & 38.0 & 3.5 & 11.0 & & 27.5 \\
\hline SML53 & 13.5 & 16.5 & V & 31.5 & 5.5 & 9.5 & & 20.5 \\
\hline Leuconostoc mesenteroides subsp. dextranicum NCFB $529^{\mathrm{T}}$ & 8.0 & 24.5 & & 33.5 & & 16.0 & & 17.0 \\
\hline Leuconostoc mesenteroides subsp. cremoris NCFB $543^{\mathrm{T}}$ & 9.5 & 31.5 & & 33.5 & & 18.0 & & 8.0 \\
\hline Leuconostoc paramesenteroides NCFB $803^{\mathrm{T}}$ & 2.0 & 4.0 & 6.0 & 25.5 & & 46.5 & & 14.0 \\
\hline Leuconostoc lactis NCFB $533^{\mathrm{T}}$ & 2.0 & 8.5 & & 33.5 & & 31.5 & 1.5 & 21.5 \\
\hline
\end{tabular}

${ }^{a}$ Each value is the mean from three analyses. $\mathrm{V}$, Detected in some analyses at a level of $<3 \%$. Abbreviations for fatty acids are illustrated by the following examples: $\mathrm{C}_{16: 0}$, straight-chain saturated hexadecanoic acid; $\mathrm{C}_{18: 1}$, monounsaturated octadecenoic acid; $\mathrm{C}_{\mathrm{cyclo}-19} \Delta 11$, cis-11,12-methyleneoctadecanoic acid.

species (Table 4 ). Cluster II strains all showed $>60 \%$ relatedness to the type strains of the subspecies of Leuconostoc mesenteroides (Leuconostoc mesenteroides subsp. mesenteroides NCFB 523, Leuconostoc mesenteroides subsp. dextranicum NCFB 529, and Leuconostoc mesenteroides subsp. cremoris NCFB 803). All of the cluster III strains showed high levels of DNA relatedness $(>70 \%)$ to the reference strains (strains SML40 ${ }^{\mathrm{T}}$ and SML49) representing the two fatty acid profile types in that cluster, whereas homology values were low (0 to $35 \%$ ) against reference strains from clusters I and II and the type strains of the previously described species.

\section{DISCUSSION}

Complete agreement was obtained between the classifications of the leuconostocs isolated from meat as determined by numerical analysis of phenotypic properties and by DNA-DNA hybridization. Both techniques revealed the presence of three groups, represented by clusters I, II, and III in the numerical study. The subdivision of cluster III into two groups indicated by the cellular fatty acid composition study was not supported by the DNA hybridization results, which showed that this cluster formed a single homology group. This is reconcilable because the differences were only in the relative amounts of the $\mathrm{C}_{19}$ cyclopropane ring acid (cis-11,12-methyleneoctadecanoate) and its precursor (cis11,12-octadecenoic acid) and in the presence or absence of the $\mathrm{C}_{17}$ cyclopropane ring acid, whose precursor (cis-9,10hexadecenoic acid) was present in both types. These represent very minor enzymatic differences (17) and would not be expected to affect genomic relatedness (26).
All three groups of leuconostocs from meat had intragroup DNA homology values of $>70 \%$, showing that each group was composed of a single species (27). The DNA-DNA hybridization results demonstrated that strains in cluster II could be assigned to Leuconostoc mesenteroides; high homology values ( $>60 \%$ ) were obtained with the type strains of all three subspecies (Leuconostoc mesenteroides subsp. mesenteroides, Leuconostoc mesenteroides subsp. dextranicum, and Leuconostoc mesenteroides subsp. cremoris). The high levels of DNA relatedness among the subspecies of Leuconostoc mesenteroides are in agreement with data from previous studies $(6,14)$. Strains in cluster II were identified as Leuconostoc mesenteroides subsp. mesenteroides on the basis of phenotypic similarity, as exemplified by the presence of the type strain (strain NCFB 523) in that cluster in the numerical phenetic analysis. The DNA-DNA hybridization results demonstrated that cluster I and III strains were unrelated to previously described species in the genus Leuconostoc. Lactobacillus confusus and Lactobacillus viridescens are difficult to separate from leuconostocs (8) but were not included in this study. However, there is evidence demonstrating that cluster I and III strains do not belong to these species. Reference strains from each cluster (strains SML9 $^{\mathrm{T}}$ and SML40 ${ }^{\mathrm{T}}$ ) exhibited low $(8 \%)$ DNA base sequence relatedness to the type strain of Lactobacillus confusus (J. A. E. Farrow, personal communication). The guanine-plus-cytosine $(\mathrm{G}+\mathrm{C})$ contents of the DNAs of representative strains from clusters I and III were 37 and 39 mol\%, respectively, which is outside the range (41 to 44 mol\%) for Lactobacillus viridescens (16). In contrast to cluster I and III strains, Lactobacillus viridescens produces 
TABLE 4. Levels of DNA homology for leuconostocs

\begin{tabular}{|c|c|c|c|c|c|c|c|c|c|c|}
\hline \multirow[b]{2}{*}{$\begin{array}{l}\text { Species or } \\
\text { subspecies }\end{array}$} & \multirow[b]{2}{*}{ Strain } & \multirow[b]{2}{*}{$\begin{array}{l}\mathrm{Mol} \% \\
\mathrm{G}+\mathrm{C}\end{array}$} & \multicolumn{8}{|c|}{$\%$ Homology with $\left[{ }^{3} \mathrm{H}\right] \mathrm{DNA}$ from: } \\
\hline & & & $\begin{array}{l}\text { Leuco- } \\
\text { nostoc } \\
\text { gelidum } \\
\text { SML9T }\end{array}$ & $\begin{array}{l}\text { Leuco- } \\
\text { nostoc } \\
\text { carnosum } \\
\text { SML40 }\end{array}$ & $\begin{array}{l}\text { Leluco- } \\
\text { nostoc } \\
\text { carnosum } \\
\text { SML49 }\end{array}$ & $\begin{array}{l}\text { Leuconostoc } \\
\text { mesenteroides } \\
\text { subsp. mesen- } \\
\text { teroides } \\
\text { NCFB } 523^{\mathrm{T}}\end{array}$ & $\begin{array}{l}\text { Leuconos- } \\
\text { toc mesen- } \\
\text { teroides } \\
\text { subsp. dex- } \\
\text { tranicum } \\
\text { NCFB } 529^{\mathrm{T}}\end{array}$ & $\begin{array}{c}\text { Leuconostoc } \\
\text { mesenter- } \\
\text { oides subsp. } \\
\text { cremoris } \\
\text { NCFB } 803^{\mathrm{T}}\end{array}$ & $\begin{array}{l}\text { Leuconos- } \\
\text { toc para- } \\
\text { mesenter- } \\
\text { oides } \\
\text { NCB } 543^{\top}\end{array}$ & $\begin{array}{c}\text { Leuconos- } \\
\text { toc lactis } \\
\text { NCFB } \\
533^{\mathrm{T}}\end{array}$ \\
\hline \multirow{5}{*}{$\begin{array}{l}\text { Leuconostoc gelidum } \\
\quad \text { (cluster I) }\end{array}$} & SML1 & 37 & 81 & 7 & 21 & 31 & 3 & 8 & 0 & 10 \\
\hline & SML3 & & 85 & 9 & 5 & 18 & 9 & 0 & 1 & 0 \\
\hline & SML7 & & 95 & 4 & 15 & 15 & 0 & 23 & 0 & 0 \\
\hline & SML9 $^{\mathrm{T}}$ & 37 & 100 & 14 & 12 & 27 & 13 & 0 & 0 & 0 \\
\hline & SML28 & & 114 & 3 & 10 & 9 & 6 & 2 & 3 & 1 \\
\hline \multirow{6}{*}{$\begin{array}{l}\text { Leuconostoc mesen- } \\
\quad \text { teroides subsp. } \\
\text { mesenteroides } \\
\text { (cluster II) }\end{array}$} & NCFB $523^{T}$ & $38^{a}$ & 16 & 13 & 1 & 100 & 92 & 75 & 0 & 0 \\
\hline & SML42 & & 4 & 10 & 13 & 77 & 67 & 69 & 6 & 0 \\
\hline & SML43 & & 2 & 9 & 10 & 96 & 94 & 106 & 2 & 0 \\
\hline & SML44 & & 32 & 12 & 14 & 95 & 60 & 94 & 5 & 2 \\
\hline & SML45 & & 12 & 6 & 15 & 91 & 69 & 97 & 2 & 7 \\
\hline & SML50 & 39 & 17 & 17 & 11 & 101 & 98 & 100 & 2 & 17 \\
\hline \multirow{10}{*}{$\begin{array}{l}\text { Leuconostoc carno- } \\
\text { sum (cluster lII) }\end{array}$} & SML31 & & 0 & 81 & 78 & 32 & 6 & 26 & 3 & 0 \\
\hline & SML33 & & 31 & 94 & 96 & 31 & 7 & 8 & 2 & 0 \\
\hline & SML34 & & 14 & 93 & 79 & 19 & 7 & 9 & 4 & 0 \\
\hline & SML35 & & 3 & 97 & 82 & 29 & 10 & 20 & 4 & 10 \\
\hline & SML38 & & 16 & 116 & 97 & 29 & 24 & 19 & 6 & 25 \\
\hline & SML $40^{\mathrm{T}}$ & 39 & 18 & 100 & 110 & 23 & 8 & 10 & 3 & 19 \\
\hline & SML48 & & 0 & 97 & 90 & 26 & 22 & 29 & 0 & 24 \\
\hline & SML49 & 39 & 20 & 97 & 100 & 25 & 10 & 12 & 4 & 10 \\
\hline & SML51 & & 2 & 82 & 112 & 25 & 19 & 2 & 0 & 5 \\
\hline & SML53 & & 12 & 76 & 81 & 26 & 11 & 17 & 0 & 0 \\
\hline $\begin{array}{l}\text { Leuconostoc mesen- } \\
\text { teroides subsp. } \\
\text { dextranicum }\end{array}$ & NCFB $529^{\mathrm{T}}$ & $38^{a}$ & 14 & 8 & 5 & 92 & 100 & 90 & 5 & 6 \\
\hline $\begin{array}{l}\text { Leuconostoc mesen- } \\
\text { teroides subsp. } \\
\text { cremoris }\end{array}$ & NCFB $543^{\mathrm{T}}$ & $39^{a}$ & 9 & 10 & 4 & 109 & 81 & 100 & 5 & 5 \\
\hline $\begin{array}{l}\text { Leuconostoc para- } \\
\text { mesenteroides }\end{array}$ & $\mathrm{NCFB} 803^{\mathrm{T}}$ & $38^{a}$ & 0 & 3 & 0 & 15 & 10 & 6 & 100 & 0 \\
\hline Leuconostoc lactis & NCFB $533^{\mathrm{T}}$ & $42^{a}$ & 0 & 22 & 7 & 25 & 14 & 0 & 0 & 100 \\
\hline
\end{tabular}

more than $5 \%$ of its lactate as the $\mathrm{L}-(+)$ isomer (16) and is capable of growth at $37^{\circ} \mathrm{C}(15)$. Therefore, cluster I and III strains warrant separate species status; we propose the names Leuconostoc gelidum sp. nov. and Leuconostoc carnosum sp. nov. for clusters I and III, respectively. These species qualify for membership in the genus Leuconostoc on the basis of the following characteristics: gram-positive, catalase-negative cocci or coccobacilli that produce gas from glucose, form more than $95 \%$ of their lactate as the $\mathrm{D}-(-)$ isomer, and do not hydrolyze arginine. Characteristics use-

TABLE 5. Diagnostic characteristics of Leuconostoc mesenteroides, Leuconostoc paramesenteroides, Leuconostoc lactis, Leuconostoc gelidum, Leuconostoc carnosum, Lactobacillus confusus, and Lactobacillus viridescens ${ }^{\text {a }}$

\begin{tabular}{|c|c|c|c|c|c|c|c|c|c|}
\hline Characteristic & $\begin{array}{l}\text { Leuconostoc } \\
\text { mesenteroides } \\
\text { subsp. mesen- } \\
\quad \text { teroides }\end{array}$ & $\begin{array}{l}\text { Leuconostoc } \\
\text { mesenteroides } \\
\text { subsp. dext- } \\
\text { ranicum }\end{array}$ & $\begin{array}{l}\text { Leuconostoc } \\
\text { mesenteroides } \\
\text { subsp. cremoris }\end{array}$ & $\begin{array}{l}\text { Leuconostoc } \\
\text { paramesen- } \\
\text { teroides }\end{array}$ & $\begin{array}{l}\text { Leuco- } \\
\text { nostoc } \\
\text { lactis }\end{array}$ & $\begin{array}{l}\text { Leuco- } \\
\text { nostoc } \\
\text { gelidum }\end{array}$ & $\begin{array}{l}\text { Leuco- } \\
\text { nostoc } \\
\text { carnosum }\end{array}$ & $\begin{array}{l}\text { Lactoba- } \\
\text { cillus } \\
\text { confusus }\end{array}$ & $\begin{array}{l}\text { Lactoba- } \\
\quad \text { cillus } \\
\text { viridescens }\end{array}$ \\
\hline \multicolumn{10}{|l|}{ Acid produced from: } \\
\hline L-Arabinose & + & - & - & $\mathrm{d}$ & - & + & - & - & - \\
\hline Arbutin & d & - & - & - & - & + & - & NT & NT \\
\hline Fructose & + & + & - & + & + & + & + & + & + \\
\hline Galactose & + & $\mathrm{d}$ & $\mathrm{d}$ & + & + & - & - & + & - \\
\hline Maltose & + & + & d & + & + & $\mathrm{d}$ & - & + & + \\
\hline Salicin & d & $\mathrm{d}$ & - & - & $\mathrm{d}$ & + & - & + & - \\
\hline Sucrose & + & + & - & + & + & + & + & + & $\mathrm{d}$ \\
\hline Trehalose & + & + & - & + & - & + & + & - & $\mathrm{d}$ \\
\hline Xylose & $\mathrm{d}$ & $\mathrm{d}$ & - & d & - & + & - & + & - \\
\hline Dextran formation & + & + & - & - & - & $\mathrm{d}$ & + & + & NT \\
\hline Growth at $37^{\circ} \mathrm{C}$ & d & + & - & d & + & - & - & + & + \\
\hline
\end{tabular}

${ }^{a}+, 90 \%$ or more of the strains positive:,$- 90 \%$ or more of the strains negative; $\mathrm{d}, 11$ to $89 \%$ of the strains positive; NT, not tested Data for Leuconostoc mesenteroides, Leuconostoc paramesenteroides, and Leuconostoc lactis are from reference 8. Data for Lactobacillus confusus and Lactobacillus viridescens are from references 15 and 16 . 
ful for differentiating these species from previously described taxa are shown in Table 5 .

Description of Leuconostoc gelidum sp. nov. Leuconostoc gelidum (ge'li.dum. L.neut.adj. gelidum, cold, (referring to the ability to grow on chill-stored meat). Gram-positive, nonmotile, nonsporeforming, spherical but sometimes lenticellular cells usually occur in pairs and chains. Colonies are small, smooth, round, and greyish white. Growth occurs at $1^{\circ} \mathrm{C}$, and most strains do not grow at $37^{\circ} \mathrm{C}$. Heterofermentative, producing gas from glucose. More than $95 \%$ of the lactate is produced as the $\mathrm{D}-(-)$ isomer. Catalase negative. Arginine is not hydrolyzed. All strains hydrolyze esculin and are $\beta$-galactosidase positive. Voges-Proskauer negative. Deoxyribonuclease positive. Does not hydrolyze Tween 20, Tween 40 , Tween 60 , or Tween 80 . Most strains produce dextran from sucrose. Acid is produced from amygdalin, L-arabinose, arbutin, cellobiose, D-fructose, D-glucose, Dmannose, melibiose, $\alpha$-methyl-D-glucoside, raffinose, salicin, sucrose, trehalose, D-xylose. Acid is not produced from D-arabinose, dulcitol, erythritol, galactose, gluconate, glycerol, inositol, lactose, mannitol, D-melezitose, rhamnose, sorbitol, or L-sorbose. Some strains produce acid from maltose and ribose.

The cellular fatty acids are of the straight-chain saturated, monounsaturated, and cyclopropane ring types, with tetradecanoic, hexadecanoic, cis-9,10-hexadecenoic, cis-11,12octadecenoic, and cis-11,12-methyleneoctadecanoic acids predominating. Small quantities of methylenehexadecanoic acid are also present. The $\mathrm{G}+\mathrm{C}$ content of the DNA of the type strain is $37 \mathrm{~mol} \%$ (as determined by the thermal denaturation method). Isolated from vacuum-packaged meat stored at low temperatures.

The type strain is strain NCFB 2775 (= SML9). The description of the type strain corresponds to that of the species, except that no growth occurs at $37^{\circ} \mathrm{C}$, dextran is produced from sucrose, acid is produced from ribose, and acid is not produced from maltose.

Description of Leuconostoc carnosum sp. nov. Leuconostoc carnosum (car.no'sum. L.neut.adj carnosum, pertaining to flesh). Gram-positive, nonmotile, nonsporeforming, spherical but sometimes lenticellular cells usually occur in pairs and chains. Colonies are small, smooth, round, and greyish white. Growth occurs at $1^{\circ} \mathrm{C}$, and most strains do not grow at $37^{\circ} \mathrm{C}$. Heterofermentative, producing gas from glucose. More than $95 \%$ of the lactate is produced as the $\mathrm{D}-(-)$ isomer. Catalase negative. Arginine is not hydrolyzed. Some strains hydrolyze esculin. All strains are $\beta$-galactosidase negative. Voges-Proskauer negative. Deoxyribonuclease positive. Does not hydrolyze Tween 20 and Tween 80 , but some strains hydrolyze Tween 40 and Tween 60 . Most strains produce dextran from sucrose. Acid is produced from D-fructose, D-glucose, $\alpha$-methyl-D-glucoside, sucrose, and trehalose. Acid is not produced from amygdalin, D-arabinose, L-arabinose, arbutin, dulcitol, erythritol, galactose, gluconate, glycerol, lactose, mannitol, D-melezitose, raffinose, rhamnose, sorbitol, L-sorbose, or D-xylose. Some strains produce acid from cellobiose, maltose, D-mannose, melibiose, ribose, and salicin.

The cellular fatty acids are of the straight-chain saturated, monounsaturated, and cyclopropane ring types, with tetradecanoic, hexadecanoic, cis-9,10-hexadecenoic, cis-11,12octadecenoic, and cis-11,12-methyleneoctadecanoic acids predominating. Some strains produce methylenehexadecanoic acid. The $\mathrm{G}+\mathrm{C}$ content of the DNA of the type strain is $39 \mathrm{~mol} \%$ (as determined by the thermal denaturation method). Isolated from vacuum-packaged meat stored at low temperatures.

The type strain is strain NCFB 2776 (= SML40). The description of the type strain corresponds to that of the species, except that no growth occurs at $37^{\circ} \mathrm{C}$, dextran is produced from sucrose, esculin is not hydrolyzed, Tween 40 and Tween 60 are not hydrolyzed, acid is produced from D-mannose and ribose, and acid is not produced from cellobiose, maltose, melibiose, or salicin.

\section{ACKNOWLEDGMENTS}

We thank C. M. Hibbard for assistance in determining cellular fatty acid compositions and J. A. E. Farrow (Institute of Food Research, Reading Laboratory, Reading, United Kingdom) for providing unpublished data.

\section{LITERATURE CITED}

1. Cavett, J. J. 1963. A diagnostic key for identifying the lactic acid bacteria of vacuum packed bacon. J. Appl. Bacteriol. 26: 453-470.

2. Crosa, J. H., D. J. Brenner, and S. Falkow. 1973. Use of a single-strand specific nuclease for analysis of bacterial and plasmid deoxyribonucleic acid homo- and heteroduplexes. J. Bacteriol. 115:904-911.

3. Garvie, E. I. 1960. The genus Leuconostoc and its nomenclature. J. Dairy Res. 27:283-292.

4. Garvie, E. I. 1987. Leuconostoc oenos sp. nov. J. Gen. Microbiol. 48:431-438.

5. Garvie, E. I. 1967. Growth factor and amino acid requirements of species of the genus Leuconostoc including Leuconostoc paramesenteroides (sp. nov.) and Leuconostoc oenos. J. Gen. Microbiol. 48:439-447.

6. Garvie, E. I. 1976. Hybridization between deoxyribonucleic acids of some strains of heterofermentative lactic acid bacteria. Int. J. Syst. Bacteriol. 26:116-122.

7. Garvie, E. I. 1978. Streptococcus raffinolactis (Orla-Jensen and Hansen): a group $\mathrm{N}$ streptococcus found in raw milk. Int. J. Syst. Bacteriol. 28:190-193.

8. Garvie, E. I. 1986. The genus Leuconostoc, p. 1071-1075. In P. H. A. Sneath, N. A. Mair, M. E. Sharpe, and J. G. Holt (ed.), Bergey's manual of systematic bacteriology, vol. 2. The Williams \& Wilkins Co., Baltimore.

9. Garvie, E. I., V. Zezula, and V. A. Hill. 1974. Guanineplus-cytosine content of the deoxyribonucleic acid of the leuconostocs and some heterofermentative lactobacilli. Int. J. Syst. Bacteriol. 24:248-251.

10. Gasser, F., and M. Hontebeyrie. 1977. Immunological relationships of glucose-6-phosphate dehydrogenase of Leuconostoc mesenteroides NCDO 768 (= ATCC 12291). Int. J. Syst. Bacteriol. 27:6-8.

11. Hanna, M. O., C. Vanderzant, G. C. Smith, and J. W. Savell. 1981. Packaging of beef loin steaks in $75 \% \mathrm{O}_{2}$ plus $25 \% \mathrm{CO}_{2}$. II. Microbiological properties. J. Food Prot. 44:928-933.

12. Hitchener, B. J., A. F. Egan, and P. J. Rodgers. 1982. Characteristics of lactic acid bacteria isolated from vacuum-packaged beef. J. Appl. Bacteriol. 52:31-37.

13. Hontebeyrie, M., and F. Gasser. 1975. Comparative immunological relationships of two distinct sets of isofunctional dehydrogenases in the genus Leuconostoc. Int. J. Syst. Bacteriol. 25:1-6.

14. Hontebeyrie, M., and F. Gasser. 1977. Deoxyribonucleic acid homologies in the genus Leuconostoc. Int. J. Syst. Bacteriol. 27:9-14.

15. Kandler, O., U. Schillinger, and N. Weiss. 1983. Lactobacillus halotolerans sp. nov., nom. rev. and Lactobacillus minor sp. nov., nom. rev. Syst. Appl. Microbiol. 4:280-285.

16. Kandler, O., and N. Weiss. 1986. The genus Lactobacillus, p. 1208-1234. In P. H. A. Sneath, N. A. Mair, M. E. Sharpe, and J. G. Holt (ed.), Bergey's manual of systematic bacteriology, vol. 2. The Williams \& Wilkins Co., Baltimore.

17. Kates, M. 1964. Bacterial lipids. Adv. Lipid Res. 2:17-90. 
18. Lowe, G. H. 1962. The rapid detection of lactose fermentation in paracolon organisms by the demonstration of $\beta$-D-galactosidase. J. Med. Lab. Technol. 19:21-25.

19. Owen, R. J., and D. Pitcher. 1985. Current methods for estimating DNA base composition and levels of DNA-DNA hybridization. Soc. Appl. Bacteriol. Tech. Ser. 20:67-93.

20. Savell, J. W., M. O. Hanna, C. Vanderzant, and G. C. Smith. 1981. An incident of predominance of Leuconostoc sp. in vacuum-packaged beef strip loins-sensory and microbial profile of steaks stored in $\mathrm{O}_{2}-\mathrm{CO}_{2}-\mathrm{N}_{2}$ atmospheres. J. Food Prot. 44:742-745.

21. Sharpe, M. E. 1979. Identification of lactic acid bacteria. Soc. Appl. Bacteriol. Tech. Ser. 14:233-259.

22. Shaw, B. G., and C. D. Harding. 1984. A numerical taxonomic study of lactic acid bacteria from vacuum-packed beef, pork, lamb and bacon. J. Appl. Bacteriol. 56:25-40.

23. Shaw, B. G., and C. D. Harding. 1985. Atypical lactobacilli from vacuum-packaged meats: comparison by DNA hybridization, cell composition and biochemical tests with a description of
Lactobacillus carnis sp. nov. Syst. Appl. Microbiol. 6:291-297.

24. Sneath, P. H. A., and R. Johnson. 1972. The influence on numerical taxonomic similarities of errors in microbiological tests. J. Gen. Microbiol. 72:377-392.

25. Sokal, R. R., and C. D. Michener. 1958. A statistical method for evaluating systematic relationships. Univ. Kans. Sci. Bull. 38:1409-1438.

26. Uchida, K., and K. Mogi. 1972. Cellular fatty acid spectra of Pediococcus species in relation to their taxonomy. J. Gen. Appl. Microbiol. 18:109-129.

27. Wayne, L. G., D. J. Brenner, R. R. Colwell, P. A. D. Grimont, O. Kandler, M. I. Krichevsky, L. H. Moore, W. E. C. Moore, R. G. E. Murray, E. Stackebrandt, M. P. Starr, and H. G. Truper. 1987. Report of the Ad Hoc Committee on Reconciliation of Approaches to Bacterial Systematics. Int. J. Syst. Bacteriol. 37:463-464.

28. Wilkinson, B. J., and D. Jones. 1977. A numerical taxonomic survey of Listeria and related lactic acid bacteria. J. Gen. Microbiol. 98:399-421. 